\title{
Chronic Mesh Infection after Incisional Hernia Repair. Factors Influencing Negative Outcomes of Complete Mesh Removal
}

\author{
Valentin Oprea ${ }^{1}$, Florin Buia', Dan Gheorghescu' ${ }^{1}$, Dan Leuca', Mihai Toma', Ovidiu Grad ${ }^{1,2}$ \\ 'Department of Surgery, "Constantin Papilian" Emergency Clinical Military Hospital, Cluj-Napoca, Romania \\ 2Department of Surgery, "Iuliu Hatieganu” University of Medicine and Pharmacy, Cluj-Napoca, Romania
}

*Corresponding author: Valentin Oprea MD, PhD Department of Surgery "Constantin Papilian" Emergency Clinical Military Hospital 22 Gral Traian Mosoiu Street Cluj-Napoca, Cluj County, Romania E-mail: opreacv31@gmail.com

\section{Rezumat}

Infecția cronică protetică după cura chirurgicală a herniilor incizionale. Factori de evoluție negativă după excizia completă a mesei

Introducere: tratamentul herniilor incizionale s-a schimbat radical în ultimii 50 de ani odată cu introducerea materialelor protetice sintetice care au scăzut incidența ratei de recidiva. Reconstrucțiile peretelui abdominal cu materiale protetice sunt însă grevate de o incidență mare de complicații severe cum ar fi infecția bacteriană, fistulele intestinale şi sindroamele aderențiale. Acestea impun sancțiuni terapeutice care reprezintă o mare provocare pentru chirurg şi pentru pacient.

Material şi metode: din ianuarie 2009 până în decembrie 2018 au fost colectate şi analizate retrospective datele pacienților operați pentru infecții cronice după protezarea peretelui abdominal pentru herniile incizionale. Comorbiditățile, localizarea protezei, indicele prognostic nutrițional (IPN), datele demografice şi rezultatele exciziei complete a protezei au fost introduse într-o bază de date SPSS.

Rezultate: au fost identificați 89 de pacienți (29 de sex masculin) care au îndeplinit criteriile de includere. Timpul mediu de la intervenție până la debutul infecției protezei a fost de $15.04 \pm 0.95$ luni. Factorul determinant pentru infecția protezei a fost infecția plăgii după intervenția primară. După excizie, în $43 \%$ din culturile bacteriene, protezele extrase s-au pozitivat pentru St. aureus, MRSA şi Enterobacter spp. Au fost utilizate mai multe tehnici de excizie protetică şi de reconstrucție a peretelui abdominal. După închiderea reconstrucției peretelui abdominal, 54\% din pacienți au dezvoltat complicații cu o mortalitate de $12 \%$. 
Concluzii: riscul de infecție după reconstrucția protetică este mai ridicat decât pentru alte intervenții curate. Excizia protezei este obligatorie când evoluția infecției este mai mare de 3 luni. Procedura este asociată cu o rată ridicată de mortalitate, morbiditate şi calitate scăzută a vieții mai ales când abdomenul nu poate fi închis. Prevenția pare singura metodă validă de tratment.

Cuvinte cheie: hernie incizională, infecția protezei, fistula entero-cutanată, excizia protezei, evoluție negativă

\section{Abstract}

Background: The treatment of incisional hernias has radically changed over the last 50 years due to the introduction of mesh repair, which has been proven to be superior to tissue repairs in terms of recurrence. Severe complications such as bacterial contamination, enteral fistulas and severe visceral adhesions are the bane of mesh repair and lead to great challenges as far as treatment is concerned.

Methods: From January 2009 to December 2018, we retrospectively collected operative and outcome data on reoperation following septic complications of incisional hernias (IH) mesh repair in 89 patients. For adjustment, comorbidities, mesh location, prognostic nutritional index (PNI) and operative time were included in an SPSS data analyzer.

Results: in the referred interval 89 patients (29 males) met the inclusion criteria. The mean time for the onset of infections $15.04 \pm 0.95$ months and the number of previous abdominal interventions varied from 1 to 5 . Wound infections were reported to be the primary factor for mesh infection. Following removal only $43 \%$ of meshes were found to be positive for bacterial infections; the most common species detected being St. aureus, MRSA and, Enterobacter spp. Different techniques of mesh removal and abdominal wall closure were used. After abdominal wall closure, $54 \%$ of patients developed post-operative complications with a mortality of $12 \%$.

Conclusion: The risk of infection after abdominal wall reconstruction (AWR) appears to be higher than other clean abdominal procedures. Mesh removal is mandatory when the infection prolonged over 3 months. The procedure is associated with a high rate of morbidity and mortality and with low quality of life if the abdomen can't be closed. Prevention is the best treatment option.

Key words: incisional hernia, chronic mesh infection, entero-cutaneous fistula, mesh removal, negative outcomes

\section{Introduction}

With the introduction of synthetic prosthetic materials the treatment of incisional hernias (IH) has been radically changed over the last 50 years. Although controversy still exists concerning mesh type, positioning and approach (open or laparoscopic), mesh repair was demonstrated to be superior in terms of recurrence in randomized trials (1-3).

Far from being harmless, the burden of these materials is given by bacterial contami- nation and subsequent infections, intestinal fistulas and severe visceral adhesions. These unexpected surgical site occurrences (SSO), although infrequent frequent, often require arduous surgical interventions and re-interventions resulting in severe sequelae (loss of domain, open abdomen, intestinal stomas) and, sometimes, death.

In this retrospective study, our main goal was to assess the outcomes and factors that negatively influencing these outcomes following complete removal of chronically 
infected mesh and entero-cutaneous fistula (ECF) in patients with previous mesh incisional hernia repair.

\section{Material and Methods}

The study was conducted between January 2009 and December 2018. Following institutional review board approval, all files of the patients with mesh infection who underwent mesh removal in the referred interval were retrospectively reviewed. Only patients with signs of abdominal wall infections or intestinal fistulas lasting minimum of 3 months after a prosthetic repair of a primary or recurrent incisional hernia have been included. Demographic variables including patient's age and gender were collected. Medical comorbidities such as Body Mass Index (BMI), Chronic Obstructive Pulmonary Disease (COPD), diabetes, smoking and alcohol habits, American Society of Anesthesia Score (ASA) score were also reported. The preoperative Onodera's Prognostic Nutritional Index (10 x serum albumin $(\mathrm{g} / \mathrm{dl})+0.005 \mathrm{x}$ total lymphocyte count $/ \mathrm{mm}^{3}$ ) was calculated to evaluate the preoperative nutritional and immunological condition (4). Types and size of mesh were identified using previous operative notes whenever was possible. We further classified mesh location into on-lay, inlay (bridging), sub-lay (retro-rectus) and under-lay (intraperitoneal) $(5-7)$. All admitted patients were investigated with standard abdominal ultrasound and contrast - enhanced CT scan, in order to establish: location and status (folded, wrinkled) of the prosthetic material, the presence of the peri-prosthetic fluid collections, fistula location and bowel involvement, and to evaluate the abdominal wall musculature status and quality. Microbiology data were preoperatively collected on all patients by swab technique. For negative results the test was repeated and combined with an ultrasound - guided puncture. All positive samples were tested with 15 antibiotics for sensitivity. The Multiple Antibiotic Resistance Index (MAR Index) was calculated using the ratio between the number of antibiotics to which an isolate is resistant and the total number of antibiotics to which it was tested (8).

Additional variables including previous surgical site infections (SSI) or a history of previous surgical debridement were also included.

\section{Surgical Technique}

Patients were admitted for the night before surgery and received an osmotic bowel preparation and the prophylaxis of deep vein thrombosis with low weight heparins according to theanesthesiologist's preference. When a skin orifice was present it was injected with $2 \mathrm{ml}$ of methylene blue, in order to evaluate the extent of mesh infection. Skin incision encompassed scar and open wounds. The abdominal cavity was entered above or below the supposed location of the mesh, along the medial border of the rectus muscle. All the viscera were sharply dissected from the abdominal wall inner surface while the infected mesh, scar and inflamed tissues were removed in bloc. When the mesh was extremely adherent to the bowel this was also resected. In the same way it was proceeded for intestinal fistulas which were "en bloc" removed with the mesh and abdominal wall. Any mesh remnants were removed. Mesh samples were sent to the microbiologist in order to identify the germs and when it was positive MAR Index was also determined. Also the whole mesh specimen was sent to the pathologist for examination. The duration of surgery and intraoperative complications were recorded.

The resulting abdominal wall defect was closed whenever was possible with the Ramirez anterior component separation technique. In some instances, the defect was allowed to remain, the skin was closed and a planned ventral hernia was proposed. The Bogota bag and Negative Wound Pressure Therapy (NPWT), followed by skin closure were the next options for the abdominal wall closure.

Outcome measures included: postoperative wound morbidity (superficial and profound SSI, hematoma, seroma, wound dehiscence), general morbidity, general mortality and 
hernia recurrence. Duration of hospital stay and Intensive Care Unit (ICU) stay were also noted.

\section{Statistical Analysis}

Data were tabulated as mean \pm standard deviation (sd). Continuous variables were analyzed by ANOVA variance test followed by unpaired 2 tail Student's $\mathrm{t}$ - test assuming unequal variance and the binary outcomes with the $\chi^{2}$ test. Pearson correlation $(r)$ was used with the regression equation. A Receiver Operating Characteristics (ROC) curve was designed to determine the specificity and sensitivity of the PNI in relation with the total amount of complications, specific complications, and also with mortality rate. Youden index was determined to calculate the optimal cut-off value of PNI. Multivariate logistic regression models were built with all the variables as the outcomes of interest of severe postoperative complications, adjusting for identified confounders. In addition to the variables of interest, the following were included for adjustment: comorbidities, mesh location, PNI, operative time. Multivariate models were calculated with the linear logistic regression and the results were shown with the Odd's ratio (OR) and the 95\% confidence interval (CI). Differences with values less than 0.05 were considered statistically significant. SPSS statistic version 22.0, 2018 (IBM Chicago, Il, USA) was used to perform the statistical analysis.

\section{Results}

Over the study period, 89 patients (29 males) with a mean age of $63.34 \pm 0.67$ (37-77) years were identified; 6 patients $(7 \%)$ were initially operated in our hospital by 3 different staff surgeons, using a lightweight macro-porous monofilament polypropylene mesh in sub-lay position. The mean time from the hernia repair to the onset of infection was $15.04 \pm 0.95$ (3 - 39) months. All patients had a mean number of previous abdominal operations of $1.6 \pm 0.1$, varying from 1 to 5 . The presence of previous wound infections was reported in 33 patients (37\%) and documented with isolated germs in 16, to which Staphylococcus aureus and MRSA were the main strains identified. In 63 patients the previously repaired incisional hernia was a primary one. The main clinical sign for admission was a chronic sinus in 55 patients, exposed mesh in 18 patients, and wound cellulitis with exteriori-zation of digestive liquids in 16 patients. Comorbidities and the results of the preoperative bacteriologic samples are listed in Table 1.

Mesh was identified as an on-lay in 31 patients $(35 \%)$, in-lay in $28(31 \%)$, sub-lay in $13(15 \%)$, and under-lay in 16 patients (18\%). The main polymeric compound has been identified as polypropylene in 80 patients, polyester in 6 and a PTFE in 3 patients. The exact type of mesh (regarding weight, filament structure and porosity) could not be identified because almost all previous operative notes did not contain such details except for patients

Table 1. Comorbidities and bacteriologic results of the preoperative samples

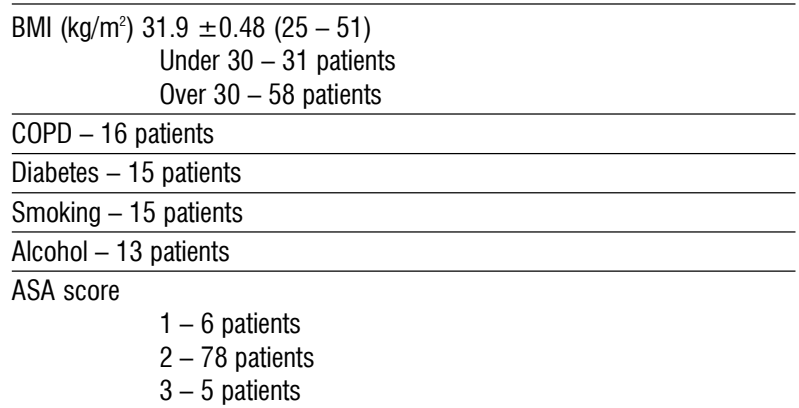

Preoperative albumin $(\mathrm{g} / \mathrm{dl})-3.21 \pm 0.04(2.1-4)$

Preoperative lymphocytes $/ \mathrm{mm}^{3}-2966 \pm 116.9(748-6120)$

Prognostic Nutritional Index (PNI) $-47.14 \pm 0.89(30.51-70.6)$

Positive samples before surgery -21 patients (24\%)

Isolated bacterial strains before surgery

Staphylococcus aureus - 16 patients

MRSA - 5 patients

Enterococcus spp - 3

MAR index

Staphylococcus aureus - 0.6

MRSA - 0.66

Enterococcus spp -0.28

BMI - Body Mass Index; COPD - Chronic Obstructive Pulmonary Disease; ASA - American Society of Anesthesiologists score; MRSA - Methicilyno - Resistant Staphylococcus Aureus; MAR Index - Multiple Antibiotic Resistance Index Normal range values for albumin $3.2-5 \mathrm{~g} / \mathrm{dl}$; Normal range values for lymphocytes is $21.8-53.1 \%$ from the count of leucocytes; Normal range leucocytes values $4.200-9.000 / \mathrm{mm}$ 
discharged from our department. Mesh was completely/almost completely removed in all patients. Mesh removal, as a unique procedure was possible only in $20 \%$ of the patients. In 30 patients, visceral resections were necessary. No stoma was performed during the index (mesh removal) procedure. The abdominal wall was closed in 63 patients (71\%), left open with temporary abdominal closure (TAC) in $10(11 \%)$ and, with a direct planned ventral hernia by skin closure in the last 16 patients (18\%). For 3 patients, who survived with the abdomen left open, the defect was closed with a skin graft after secondary healing (2 patients) and with anterior component separation (1 patient). The mean time from temporary abdominal closure to definitive closure was $7.8 \pm 0.73$ days $(6-17)$. Intraoperative details are listed in Table 2.
After the explanted prosthesis were sent for bacteriological examination, postoperative positive samples and germ identification increased to $43 \%$ of the patients. In 11 samples only one germ was identified (St. aureusin 4, MRSA in 4, and Enterobactersppin 3 patients) while in the final samples, 2 different strains were isolated. The postoperative MAR Index ranged between 0.26 and 0.86 .

The mean duration of surgery was $165.35 \pm$ 8.19 minutes with limits ranging from 45 minutes to 382 minutes. Overall, 48 patients (54\%) developed postoperative local and general complications. Wound events were reported in 38 patients and included: SSI in 18 (out of which 12 were noted as superficial), seroma - in 12, and hematoma - in 8 patients. Except seroma, all wound events imposed reintervention for debridement or hemostasis. Anastomotic leakage was noted in 6 patients

Table 2. Details of the surgical procedures and outcomes related to every type of mesh location

\begin{tabular}{|c|c|c|c|c|c|}
\hline Variable & Number (\%) & On-lay & Inlay & Sub-lay & Under-lay \\
\hline Mesh removal only & $18 / 89(20 \%)$ & $18 / 32(56 \%)$ & $0 / 28$ & $0 / 13$ & $0 / 16$ \\
\hline Abdominal wall resection & $24 / 89(27 \%)$ & $14 / 32(44 \%)$ & $0 / 28$ & $10 / 13(77 \%)$ & $0 / 16$ \\
\hline Small bowel resection & $19 / 89(21 \%)$ & $0 / 32$ & $9 / 28(32 \%)$ & $1 / 13(8 \%)$ & $9 / 16(56 \%)$ \\
\hline Large bowel resection & $5 / 89(6 \%)$ & $0 / 32$ & $2 / 28(7 \%)$ & $0 / 13$ & $3 / 16(19 \%)$ \\
\hline Combined bowel resections & $6 / 89(7 \%)$ & $0 / 32$ & $2 / 28(7 \%)$ & $0 / 13$ & $4 / 16(25 \%)$ \\
\hline Simple fascial closure & $35 / 89(39 \%)$ & $22 / 32(69 \%)$ & $13 / 28(46 \%)$ & $0 / 13$ & $0 / 13$ \\
\hline Anterior Component Separation (ACS) & $28 / 89(31 \%)$ & $10 / 32(31 \%)$ & $15 / 28(54 \%)$ & $2 / 13(15 \%)$ & $1 / 16(6 \%)$ \\
\hline Bogota bag + ACS & $1 / 89(1 \%)$ & $0 / 32$ & $0 / 28$ & $1 / 13(8 \%)$ & $3 / 16(19 \%)$ \\
\hline NPWT + skin graft & $2 / 89(2 \%)$ & $0 / 32$ & $0 / 28$ & $1 / 13(8 \%)$ & $5 / 16(31 \%)$ \\
\hline Simple skin closure & $16 / 89(18 \%)$ & $0 / 32$ & $0 / 28$ & $9 / 13(69 \%)$ & $7 / 16(44 \%)$ \\
\hline $\begin{array}{l}\text { Duration of surgery (minutes) ( mean and sd) } \\
(45-382)\end{array}$ & $\begin{array}{l}165.35 \pm 8.19 \\
(45-90)\end{array}$ & $\begin{array}{l}73.16 \pm 6.9 \\
(58-125) \\
\end{array}$ & $\begin{array}{l}92.14 \pm 9.7 \\
(75-150)\end{array}$ & $\begin{array}{l}101.7 \pm 12.4 \\
(125-382) \\
\end{array}$ & $139.3 \pm 18.5$ \\
\hline $\begin{array}{l}\text { Hospital stay (days) ( mean and sd) } \\
\quad(5-65)\end{array}$ & $\begin{array}{l}15.21 \pm 1.5 \\
(5-16)\end{array}$ & $\begin{array}{l}11.5 \pm 1.6 \\
(9-21)\end{array}$ & $\begin{array}{l}14.7 \pm 3.1 \\
(11-17)\end{array}$ & $\begin{array}{l}15.1 \pm 2.1 \\
(17-65)\end{array}$ & $18.2 \pm 3.6$ \\
\hline $\begin{array}{l}\text { ICU stay (days) ( mean and sd) } \\
(7-61)\end{array}$ & $\begin{array}{l}36.53 \pm 4.38 \\
(1-2)\end{array}$ & $\begin{array}{l}1.3 \pm 0.1 \\
(6-19)\end{array}$ & $\begin{array}{l}11.7 \pm 2.9 \\
(3-12)\end{array}$ & $\begin{array}{l}4.2 \pm 0.8 \\
(22-65)\end{array}$ & $39.5 \pm 9.3$ \\
\hline $\begin{array}{l}\text { Number of procedures/patient } \\
(1-8)\end{array}$ & $\begin{array}{l}1.85 \pm 0.14 \\
(1-2)\end{array}$ & $\begin{array}{l}1.3 \pm 0.1 \\
(1-4)\end{array}$ & $\begin{array}{l}1.6 \pm 0.3 \\
(1-2)\end{array}$ & $\begin{array}{l}1.3 \pm 0.1 \\
(1-8)\end{array}$ & $2.6 \pm 0.6$ \\
\hline Superficial SSI & 12 patients $(13 \%)$ & 5 & 4 & 1 & 2 \\
\hline Profound SSI & 6 patients $(7 \%)$ & 0 & 2 & 1 & 3 \\
\hline Seroma & 12 patients (13\%) & 10 & 0 & 1 & 1 \\
\hline Hematoma & 8 patients $(9 \%)$ & 6 & 1 & 1 & 0 \\
\hline Anastomotic leakage & 6 patients $(7 \%)$ & 0 & 2 & 0 & 4 \\
\hline Mortality & 11 patients (12\%) & 1 & 4 & 1 & 5 \\
\hline Anastomotic leakage & 4 patients & 0 & 1 & 0 & 3 \\
\hline Sepsis & 3 patients & 0 & 1 & 0 & 2 \\
\hline Pulmonary embolism & 2 patients & 0 & 1 & 1 & 0 \\
\hline Myocardial infarction & 1 patient & 0 & 1 & 0 & 0 \\
\hline Abdominal Compartment Syndrome & 1 patient & 1 & 0 & 0 & 0 \\
\hline
\end{tabular}


(20\% of all patients with visceral resections), all of them requiring surgical exploration for signs of peritonitis. In all patients, a stoma was created and the abdomen was left open on a Bogota bag (4 patients) or on NWPT. Hospital stay ranged from 5 to 65 days with a mean of $15.21 \pm 1.5$. For the severely complicated patients, the mean stay in the Intensive Care Unit was $36.53 \pm 4.38$ (Table 2).

The mean number of surgical procedures/ patient for the whole cohort was $1.85 \pm 0.14$ but when we analyzed only patients with local complications the number increased, becoming almost doubled, with a mean of $3.3 \pm 0.24$ (2 -8).

Mortality was recorded in $12 \%$ of the patients. 4 patients died after complicated anastomotic leakages with multiple organ failure, 3 - from wound sepsis and open abdomen, and 1, with multiple organ failure due to an abdominal compartment syndrome after an anterior component separation. The rest of the causes of mortality are detailed in Table 3.

The mean time of follow-up was $41.5 \pm 9.4$ months ( $11-71$ months). At 1 year 63 patients from the survival group were clinically

Table 3. Factors that independently influence the postoperative outcomes in both uni- and multivariate analysis

\begin{tabular}{|c|c|c|c|c|c|c|}
\hline Variables & Complications & Anastomotic leaks & Mor & & & \\
\hline & univariate & multivariate & univariate & multivariate & univariate & multivariate \\
\hline Age & $\begin{array}{l}r=-.158 \\
p=.138\end{array}$ & $p>.05$ & $\begin{array}{l}r=-.027 \\
p=.801\end{array}$ & $p>.05$ & $\begin{array}{l}r=-.032 \\
p=.763\end{array}$ & $p>.05$ \\
\hline Gender & $\begin{array}{l}r=.019 \\
p=.863\end{array}$ & $p>.05$ & $\begin{array}{l}r=-.004 \\
p=.968\end{array}$ & $p>.05$ & $\begin{array}{l}r=.115 \\
p=.282\end{array}$ & $p>.05$ \\
\hline Onset & $\begin{array}{l}r=.013 \\
p=.901\end{array}$ & $p>.05$ & $\begin{array}{l}r=.034 \\
p=.754\end{array}$ & $p>.05$ & $\begin{array}{l}r=.090 \\
p=.404\end{array}$ & $p>.05$ \\
\hline $\begin{array}{l}\text { Abdominal } \\
\text { operations }\end{array}$ & $\begin{array}{l}r=-.139 \\
p=.194\end{array}$ & $p>.05$ & $\begin{array}{l}r=.005 \\
p=.894\end{array}$ & $p>.05$ & $\begin{array}{l}r=.149 \\
p=.163\end{array}$ & $p>.05$ \\
\hline Recurrences & $\begin{array}{l}r=-.122 \\
p=.253\end{array}$ & $p>.05$ & $\begin{array}{l}r=.103 \\
p=.339\end{array}$ & $p>.05$ & $\begin{array}{l}r=.137 \\
p=.201\end{array}$ & $p>.05$ \\
\hline$\overline{\mathrm{BMI}}$ & $\begin{array}{l}r=-.163 \\
p=.126\end{array}$ & $p>.05$ & $\begin{array}{l}r=.130 \\
p=.225\end{array}$ & $p>.05$ & $\begin{array}{l}r=.130 \\
p=.224\end{array}$ & $p>.05$ \\
\hline$\overline{\mathrm{COPD}}$ & $\begin{array}{l}r=-.108 \\
p=.312\end{array}$ & $p>.05$ & $\begin{array}{l}r=.341 \\
p=.001\end{array}$ & $\begin{array}{l}\mathrm{OR}=0.0360 \\
95 \% \mathrm{Cl} 0.0039-0.328 \\
p=.034\end{array}$ & $\begin{array}{l}r=.269 \\
p=.011\end{array}$ & $\begin{array}{l}\mathrm{OR}=.048 \\
95 \% \mathrm{Cl}=.0096-.247 \\
p=.0003\end{array}$ \\
\hline Diabetes & $\begin{array}{l}r=.036 \\
p=.737\end{array}$ & $p>.05$ & $\begin{array}{l}r=.118 \\
p=.269\end{array}$ & $p>.05$ & $\begin{array}{l}r=.013 \\
p=.901\end{array}$ & $p>.05$ \\
\hline Smoking & $\begin{array}{l}r=.157 \\
p=.140\end{array}$ & $p>.05$ & $\begin{array}{l}r=.01 \\
p=.99\end{array}$ & $p>.05$ & $\begin{array}{l}r=.105 \\
p=.330\end{array}$ & $p>.05$ \\
\hline$\overline{\mathrm{ASA}}$ & $\begin{array}{l}r=-.102 \\
p=.343\end{array}$ & $p>.05$ & $\begin{array}{l}r=.007 \\
p=.813\end{array}$ & $p>.05$ & $\begin{array}{l}r=.112 \\
p=.214\end{array}$ & $p>.05$ \\
\hline Mesh location & $\begin{array}{l}r=-.239 \\
p=.024\end{array}$ & $\begin{array}{l}\mathrm{OR}=3.36 \\
95 \% \mathrm{Cl} 1.87-6.02\end{array}$ & $\begin{array}{l}r=.291 \\
p=.006\end{array}$ & $\begin{array}{l}\mathrm{OR}=4.88 \\
95 \% \mathrm{Cl} .54-43.54 \\
\mathrm{p}=.015\end{array}$ & $\begin{array}{l}r=.323 \\
p=.002\end{array}$ & $\begin{array}{l}\mathrm{OR}=.21 \\
95 \% \mathrm{Cl}=.044-1.06 \\
p=.05\end{array}$ \\
\hline Operative time & $\begin{array}{l}r=-.032 \\
p=.769\end{array}$ & $\begin{array}{l}\text { OR }=23.5 ; \\
95 \% \mathrm{Cl} 2.97-186.6 ; \\
p=.0028\end{array}$ & $\begin{array}{l}r=.332 \\
p=.001\end{array}$ & $\begin{array}{l}\mathrm{OR}=.037 \\
95 \% \mathrm{Cl}=.001-.67 \\
\mathrm{p}=.02\end{array}$ & $\begin{array}{l}r=.304 \\
p=.004\end{array}$ & $p>.05$ \\
\hline Albumin & $\begin{array}{l}r=.182 \\
p=.088\end{array}$ & $p>.05$ & $\begin{array}{l}r=-.328 \\
p=.002\end{array}$ & $p>.05$ & $\begin{array}{l}r=.392 \\
p=.000\end{array}$ & $p>.05$ \\
\hline Leucocytes & $\begin{array}{l}r=.081 \\
p=.453\end{array}$ & $p>.05$ & $\begin{array}{l}r=.07 \\
p=.0776\end{array}$ & $p>.05$ & $\begin{array}{l}r=.07 \\
p=.0886\end{array}$ & $p>.05$ \\
\hline Lymphocytes & $r=-.158$ & $p>.05$ & $\begin{array}{l}r=-.394 \\
p=.000\end{array}$ & $p>.05$ & $\begin{array}{l}r=-.291 \\
p=.006\end{array}$ & $p>.05$ \\
\hline$\overline{\mathrm{PNI}}$ & $\begin{array}{l}r=.301 \\
p=.004\end{array}$ & $\begin{array}{l}\text { OR }=0.336 \\
95 \% \text { Cl } 0.15-0.71 \\
p=.0047\end{array}$ & $\begin{array}{l}r=-.394 \\
p=.000\end{array}$ & $\begin{array}{l}\mathrm{OR}=.073 \\
95 \% \mathrm{Cl}=.008-.66 \\
\mathrm{p}=.021\end{array}$ & $\begin{array}{l}r=-.427 \\
p=.000\end{array}$ & $\begin{array}{l}\mathrm{OR}=.0821 \\
95 \% \mathrm{Cl} .016-.407 \\
\mathrm{p}=.0022\end{array}$ \\
\hline Anastomotic leak & & & & $p>.05$ & $\begin{array}{l}r=.307 \\
p=.03\end{array}$ & $p>.05$ \\
\hline ICU stay & & & & $p>.05$ & $\begin{array}{l}r=.802 \\
p=.001\end{array}$ & $p>.05$ \\
\hline
\end{tabular}

$\mathrm{BMI}$ - Body Mass Index (kg/m2); COPD - Chronic Obstructive Pulmonary Disease; PNI - Prognostic Nutritional Index; ICU - Intensive Care Unit 
examined (48 of them with abdomen closed after mesh excision). In the group of patients with the closed abdomen, more than half (26 patients) developed incisional hernias. From the rest of the patients, 18 were with a stable abdomen, and 19 the planned ventral enlarging. All of the patients with $\mathrm{IH}$ declined surgical repair.

Complications rate was highly correlated with mesh location and preoperative PNI in a univariate analysis. Logistic regression with adjustment for positive variable showed that mesh location (for inlay and underlay) and PNI are the only independent risk factors for the development of postoperative complications (OR 3.36; 95\%CI $1.87-6.02, \mathrm{p}<.0001$ respective OR $0.337,95 \%$ CI $0.15-0.71, \mathrm{p}=$ .0047). The increased incidence of anastomotic leaks was correlated with: the presence of COPD, mesh location, duration of surgery, PNI, lymphocytes count and albumin. In logistic regression the only independent factors for fistula were: COPD, duration of surgery, mesh location for inlay and underlay position, and PNI. The same factors were directly involved in the incidence of postoperative deaths (Table 3).

To determine the sensitivity and specificity of the factors involved in postoperative morbidity and mortality, individual and multiple ROC curves were created for: PNI, duration of surgery, mesh location, and presence of comorbidities. Duration of surgery was highly specific for predicting mortality and anastomotic leakage (98\% specificity), but not a valid model for the overall rate of complications. The cutoff time for the duration of surgery, which predicted unfavorable outcomes and deaths was 125 minutes $\left(\mathrm{J}_{\max }=0.81\right)$.

PNI was highly specific for the overall rate of complications (area under curve 0.867; 98\% specificity for a cutoff of 37; $\mathrm{J}_{\max }=0.76$ ), but not a valid predictor for fistula formation and postoperative mortality (Fig. 1).

Mesh location for inlay and under - lay position demonstrated high specificity in relation with fistula formation (area under curve $0.799,88 \%$ ) along with postoperative death (area under curve 0.753; 88\%) (Fig. 2).

Regarding comorbidities, COPD and obesity were the only specific factors predicting complications, anastomotic leakage, and mortality (data not shown).

\section{Discussion}

Natural history of IH is prone to complications: pain, increasing size, poor cosmetics , poor abdominal wa ll function, low quality of life, and increasing risk of strangulation and incarceration (9). An optimal approach has to be identified, but there is one consensus: mesh repair is mandatory (1-3). Mesh repair refined the existent surgical techniques allowing complex cases to be solved and offering a
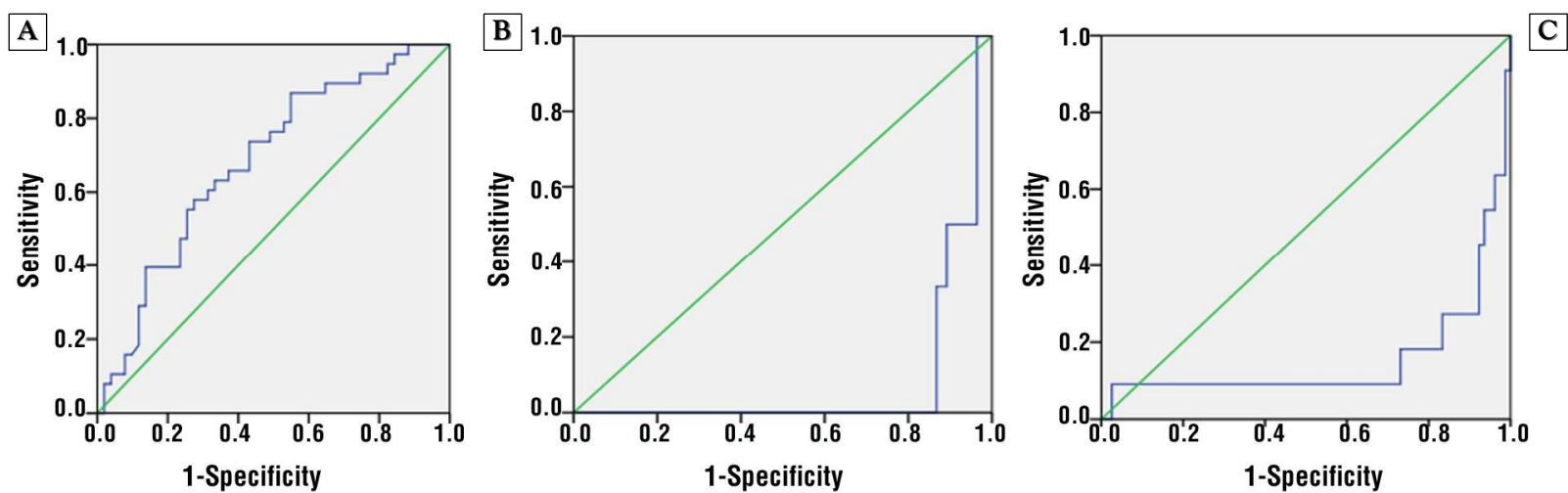

Figure 1. Individual Receiver Operating Curve (ROC) curve for "Prognostic Nutritional Index" in relation with overall complications rate (A), fistula presence (B), and postoperative mortality (C). Model is valid only for the complications rate (area under curve 0.897) but highly nonspecific for the presence of anastomotic fistula (B) and for mortality (C) 

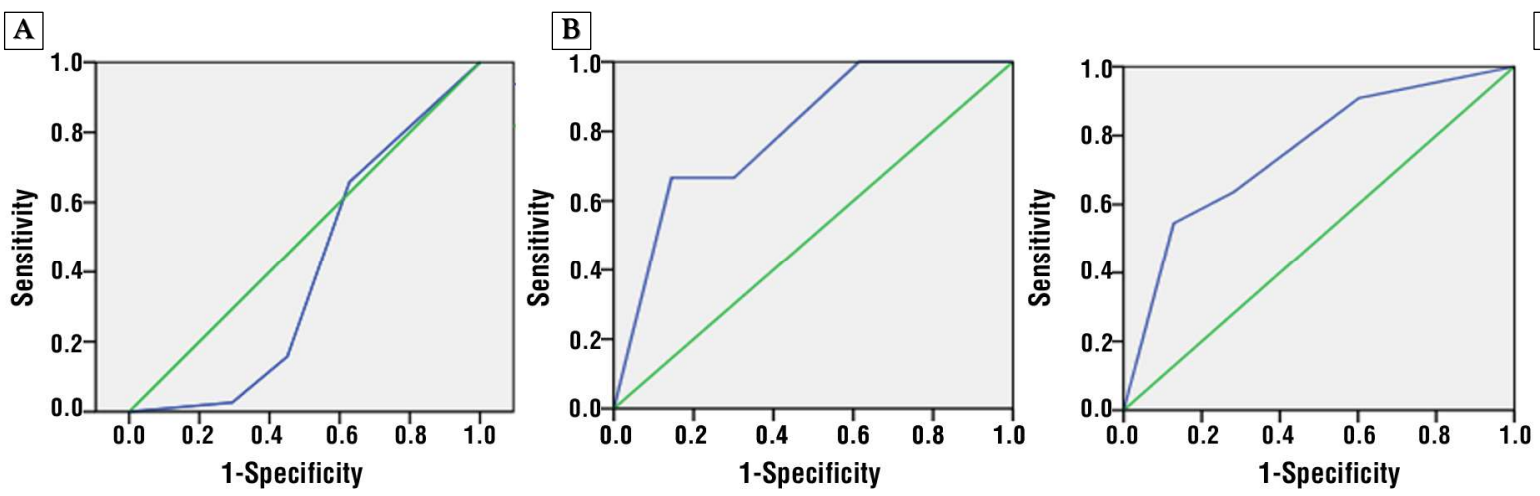

Figure 2. Individual Receiver Operating Curve (ROC) curve for "Mesh location inlay and under-lay" in relation with overall complications rate (A), fistula presence (B), and postoperative mortality (C). Model is not valid for complications rate (area under curve 0.397) but highly specific for the presence of anastomotic fistula (B) (area under curve 0.799) and for mortality (C) (area under curve 0.753)

real chance of social reinsertion with better healthcare outcomes for patients.

Even though the quality of the prosthetic materials has undergone successive improvements over time, their use is still associated with severe complications: intestinal obstruction, mesh infection, entero-cutaneous fistula (ECF). Infection plays the number one role in major device - related complications. It can lead to severe and costly consequences, severe impact on patients' life (disability, suffering, economic loss), prolonged hospitalization, and multiple re-interventions (10-12).

The risk of infection after abdominal wall mesh reconstruction appears to be higher than in other clean cases. A study from Schumpelink et al, emphasizes that patients with mesh repair have a 3 times higher risk ratio for infection than non-mesh repairs (13).

Some would advocate that mesh infection is a complication frequently observed only in the early postoperative period; although the first year may be important for the majority of mesh infections, in some studies, there is a large body of evidence showing that the complication occurs later (10). In our study, $44 \%$ of the patients reported the infection onset after more than 12 months from the last mesh repair. Infection occurred without a history of the outbreak of infections or unknown sepsis outstanding from previous intervention in 53 patients.

Chronic mesh infection is unique because bacteria adhere to the mesh surface and create a microenvironment called "biofilm" (Bi) (12-16). By its tridimensional structure, Bi provides mechanical stability to the bacteria and physical protection from outside stressors (immune cells and therapeutic compounds including antibiotics), making ineffective any measure of conservative treatment (12).

If there is an agreement that infected mesh must be removed, controversy remains regarding complete or partial mesh removal. Complete mesh removal is usually associated with increased complication rates, hernia recurrence and increased associated morbidity, and even mortality. Intestinal resection was needed in 30 patients (34\%) due to dense adhesions between prosthetic surface and bowel or migration of the mesh into the small or large bowel. As a consequence, anastomotic leakage was the most serious complication and reason for re-intervention. The same results were obtained by Bueno-Lledò et al, who reported $13.1 \%$ intestinal resections after complete mesh removal with $7,8 \%$ intestinal fistula and $10.5 \%$ re-intervention (10).

An alternative to total removal of the mesh is the partial removal of the prosthesis. In Sabbagh series, partial removal of the mesh was associated with healing in every case and the postoperative morbidity was nil but the patients still required up to five operations for healing to take place (17). In another study, Bueno-Lledo found that $50 \%$ of the patients 
with partial mesh removal continue with a discharging sinus needing complete mesh removal for healing (18).

The goals of surgery are not only to remove the infected mesh, or control the infection, and achieve wound healing. but also to address the abdominal wall defect and to prevent hernia recurrence. This is a thorny issue and until now, no satisfactory standard treatment was developed. The recommended treatments include primary closure with suture or mesh repair or staged operations with a 6 months minimum gap between procedures (19).

We don't use any mesh for the abdominal wall repair after mesh explantation. Closure of the abdomen with simple suture or anterior component separation was associated, in our series, with high rates of SSO, SSI, and increased rates of recurrences. The multistaged approach was tailored in our study for the patients with prolonged operative time, associated comorbidities, large intestinal resections and more than one anastomosis, and for the patients with a compromised immune and nutritional status. When PNI was under the cut-off value of 37 the abdomen was closed by skin suture or was left open with various TAC methods and a planned ventral hernia was preferred.

Several factors have been identified to be associated with poor outcomes after mesh removal. Mesh location for inlay and underlay and PNI are the only independent risk factors for development of postoperative complications. Incidence of the fistula was independently related to the presence of COPD, duration of surgery, mesh location for inlay and underlay position, and PNI. The same factors were directly involved in the incidence of postoperative deaths. An operative time longer than 125 minutes was found highly specific in predicting mortality and anastomotic leakage. PNI was highly specific for the overall rate of complications. A high specificity demonstrated mesh location for inlay and under-lay position in relation with fistula formation (area under curve $0.799,88 \%$ ) and for postoperative deaths (area under curve 0.753; 88\%). Regarding morbidities, COPD and obesity were the only specific factors predicting complications, anastomotic leakage, and mortality. All of them are correctable factors before surgery in the patient's optimization process.

To our knowledge, this study seems to be the first large series of mesh infections reported in our surgical literature. Though not new, the results of our research are in accordance with previously published western literature and confirm once again the difficulties induced by the presence of the mesh in contact with the bowels. Our contribution could be important due to the large number of operated cases with unexpected, challenging intra-operative situations in a series of complex patients.

Our study is not without limitations. Retrospective chart review was limited by the incomplete medical information collected from the patient's files as well as the bias of the reviewers. Our patient population was almost exclusively referred to resolve a severe complication. Also, it spans a long period of time, but given the relatively low incidence of the cases and long-time lapse manifestation, it is not possible to construct a randomized trial in a reasonable time frame. The degree of contamination cannot be predicted or anticipated preoperatively so, intraoperative findings can alter the risk of mesh explantation. Finally, the entire cohort was heterogeneous, and also, included a large different amount of procedures both involving a serious bias. The applicability of this data to other patient population should be approached cautiously.

\section{Conclusions}

Mesh infection after IH repair is a severe and debilitating condition. Complete mesh removal seems to be the only valid therapeutic option but generates a high early and late severe complication rates with increased morbidity (in terms of SSO and SSI) and mortality. Factors that negatively influenced the outcomes of complete mesh removal are: mesh location as in-lay and under-lay, decreased PNI (under 37), prolonged operative time (over 120 minutes), and co-morbidities especially COPD. Abdominal 
wall closure after mesh removal is challenging and no satisfactory standard treatment till now has been developed. The rate of incisional hernia after the closure of the abdominal wall remains high. Multi - staged approach for the abdominal wall closure is an inconvenient long - term solution, but could be a valid option in selected cases with obese, co-morbid patients and increased risk of fistulas. Patient's optimization is mandatory and aims correction of the nutritional status in patients with PNI under 37 , correction of the respiratory status and sometimes staged repair when these targets can't be achieved. Practically, patient referral to a specialized center or to an experienced dedicated surgeon could be a valid option to avoid major complications.

\section{Authors Contribution}

OV - design concept, data collecting and interpretation, writing the manuscript, revising and final approval; FB, DG, DL, MT, and OG - reading, revising and approval of the final form.

\section{Conflict of Interest}

The authors declare no conflicts of interests.

Source of Founding: none.

\section{Ethical Approval}

All procedures performed in studies involving human participants were in accordance with the ethical standards of the institutional and/ or national research committee and with the 1964 Helsinki declaration and its later amendments or comparable ethical standards.

\section{References}

1. Luijendijk RW, Hop WC, van den Tol MP, de Lange DC, Braaksma MM,
IJzermans $\mathrm{JN}$, et al. A comparison of suture repair with mesh repair for incisional hernia. N Engl J Med. 2000; 343(6):392-8

2. Nieuweihnhuizen J, Eker HH, Timmermans L, Hop WC, Kleinrensink GJ, Jeekel $\mathrm{J}$, et al. A double blind randomized controlled trial comparing primary suture closure with mesh augmented closure to reduce incisional hernia incidence. BMC Surg. 2013;13:48.

3. Burger JWA, Luijendijk RW, Hop WC, Halm JA, Verdaansdonk EGG, Jeekel J. Long-term follow-up of a randomized controlled trial of suture versus mesh repair of incisional hernia. Ann Surg. 2004;240(4):578-83; discussion 583-5.

4. Onodera T, Goseki N, Kosaki G. Prognostic nutritional index in gastrointestinal surgery of malnourished cancer patients. Nihon Geka Gakkai Zasshi. 1984:85(9):1001-5. Japanese

5. Parker SG, Halligan S, Liang M, Muysoms F, Adrales G, Boutall A, et al. International classification of abdominal wall planes (ICAP) to describe mesh insertion for ventral hernia repair. Br J Surg. 2020;107(3):209-217 .

6. Holihan JL, Liang MK. Nomenclature in ventral hernia repair. World J Surg. 2018;42(6):1904-1905.

7. Muysoms F, Jacob B. International hernia collaboration consensus on nomenclature of abdominal wall hernia repair. World J Surg. 2018;42(1): 302-304.

8. Paul S, Bezbaruah RL, Roy MK, Ghosh AC. Multiple antibiotic resistance (MAR) index and its reversion in Pseudomonas aeruginosa. Lett Appl Microbiol. 1997;24(3):169-71.

9. Liang MK, Li TL, Nguyen MT, Berger RL, Hicks SC, Kao LS. Abdominal reoperation and mesh explantation following open ventral hernia repair with mesh. Am J Surg. 2014;208(4):670-6.

10. Bueno-Lledó J, Torregrosa-Gallud A, Sala-Hernandez A, Carbonell-Tatay F, Pastor PG, Diana SB, et al. Predictors of mesh infection and explantation after abdominal wall hernia repair. Am J Surg. 2017;213(1):50-57.

11. Schumpelick V, Klinge U, Stumpf M. Treatment of Infections after Open Ventral Herniorrhaphy. In Deysine M (ed), Hernia Infections. Diagnosis. Treatment. Prevention. New-York, Basel: Marcel Dekker Inc; 2004; p. 207-215.

12. Romanò $\mathrm{CL}$, Romanò D, Morelli I, Drago L. The Concept of Biofilm-Related Implant Malfunction and "Low-Grade Infection". Adv Exp Med Biol. 2017:971:1-13

13. Jacombs ASW, Karatassas A, Klosterhalfen B, Richter K, Pattiniol P, Hensman C. Biofilms and effective porosity of mesh: are they silent assassins? Hernia. 2020;24(1):197-204.

14. Klinge U, Klosterhalfen B, Birkenhauer U, Junge K, Conze J, Schumpelick V. Impact of polymer pore size on the interface scar formation in a rat model. $J$ Surg Res. 2002;103(2):208-14.

15. Bury K, Smietanski M, Justina B, Gunietal P, Smietanska Al, Owczuk R, et al - Effects of macroporous monofilament mesh on infection in a contaminated field. Langenbecks Arch Surg. 2014;399(7):873-7.

16. Pascual G. Hernández-Gascón B, Rodriguez M, Sotomayor S, Pena E, Calvo $B$, et al - The long-term behavior of lightweight and heavyweight meshes to repair abdominal wall defects is determined by the host tissue repair process provoked by the mesh. Surgery. 2012;152(5):886-95.

17. Sabbagh $C$, Verhaeghe $P$, Brehant 0 , Browet $F$, Garriot B, Regimbeau JM. Partial removal of infected parietal meshes is a safe procedure. Hernia 2012;16(4):445-449.

18. Bueno-Lledó J, Torregrosa-Gallud A, Carreno-Saénz 0, García-Pastor P, Carbonell-Tatay F, Bonaté-Diana S, et al - Partial versus complete removal of the infected mesh after abdominal wall hernia repair. Am J Surg. 2017; 214(1):47-52.

19. Engelsman AF, van Dam GM, van der Mei HC, Busscher HJ, Ploeg RJ. In vivo evaluation of bacterial infection involving morphologically different surgical meshes. Ann Surg. 2010;251(1):133-7. 